\begin{tabular}{|l|l|l||}
\hline \multicolumn{2}{|c|}{ PublisherInfo } \\
\hline \hline PublisherName & $:$ & BioMed Central \\
\hline \hline PublisherLocation & $:$ & London \\
\hline \hline PublisherImprintName & $:$ & BioMed Central \\
\hline \hline
\end{tabular}

\title{
Tall, skinny, RNAi decaf, to go
}

\begin{tabular}{|l|c|l||}
\hline \multicolumn{2}{|c|}{ ArticleInfo } \\
\hline \hline ArticleID & $:$ & 4798 \\
\hline \hline ArticleDOI & $:$ & $10.1186 /$ gb-spotlight-20030620-03 \\
\hline \hline ArticleCitationID & $:$ & spotlight-20030620-03 \\
\hline \hline ArticleSequenceNumber & $:$ & 150 \\
\hline \hline ArticleCategory & $:$ & Research news \\
\hline ArticleFirstPage & $:$ & 1 \\
\hline \hline ArticleLastPage & $:$ & 2 \\
\hline \hline & & RegistrationDate : 2003-6-20 \\
\hline ArticleHistory & $:$ & OnlineDate \\
\hline \hline ArticleCopyright & $:$ & BioMed Central Ltd2003-6-20 \\
\hline \hline ArticleGrants & $:$ & \\
\hline \hline ArticleContext & $:$ & 130594411 \\
\hline \hline
\end{tabular}




\section{Tudor Toma}

Email: t.toma@imperial.ac.uk

Decaffeinated coffee is increasingly popular because it lacks the stimulatory effects of caffeine that can trigger palpitations, increased blood pressure, and insomnia. Currently, coffee is decaffeinated by an expensive industrial process that also alters the flavor and quality of the finished product. In a Brief Communication in the June 19 Nature, Shinjiro Ogita and colleagues at the Nara Institute of Science and Technology show that RNA interference (RNAi) can be used to produce decaffeinated coffee plants (Nature 2003, 423:823).

Ogita et al. constructed transgenic coffee plants in which expression of the gene encoding theobromine synthase (CaMXMT1), an enzyme involved in caffeine synthesis, was repressed by RNAi. They observed that the transgenic phenotypes were normal when compared to wild-type plants. However, the young leaves of transgenic lines showed a 30 to $80 \%$ reduction in theobromine content and a 50 to $70 \%$ reduction in caffeine content in comparison with controls.

"Our method not only shortens the breeding period, which is 25 years for conventional crossing, but also opens the way to develop new species of coffee plant," conclude the authors.

\section{References}

1. Effects of caffeine on human behavior

2. Nature, [http://www.nature.com/nature]

3. Nara Institute of Science and Technology, [http://www.aist-nara.ac.jp/] 